\title{
Core Self-Evaluations in Germany
}

Citation for published version (APA):

Stumpp, T., Muck, P. M., Hülsheger, U. R., Judge, T., \& Maier, G. W. (2010). Core Self-Evaluations in Germany: Validation of a German Measure and its Relationships with Career Success. Applied Psychology: an international review, 59(4), 674-700. https://doi.org/10.1111/j.1464-0597.2010.00422.x

Document status and date:

Published: 01/10/2010

DOI:

10.1111/j.1464-0597.2010.00422.x

Document Version:

Publisher's PDF, also known as Version of record

Document license:

Taverne

Please check the document version of this publication:

- A submitted manuscript is the version of the article upon submission and before peer-review. There can be important differences between the submitted version and the official published version of record.

People interested in the research are advised to contact the author for the final version of the publication, or visit the DOI to the publisher's website.

- The final author version and the galley proof are versions of the publication after peer review.

- The final published version features the final layout of the paper including the volume, issue and page numbers.

Link to publication

\footnotetext{
General rights rights.

- You may freely distribute the URL identifying the publication in the public portal. please follow below link for the End User Agreement:

www.umlib.nl/taverne-license

Take down policy

If you believe that this document breaches copyright please contact us at:

repository@maastrichtuniversity.nl

providing details and we will investigate your claim.
}

Copyright and moral rights for the publications made accessible in the public portal are retained by the authors and/or other copyright owners and it is a condition of accessing publications that users recognise and abide by the legal requirements associated with these

- Users may download and print one copy of any publication from the public portal for the purpose of private study or research.

- You may not further distribute the material or use it for any profit-making activity or commercial gain

If the publication is distributed under the terms of Article $25 \mathrm{fa}$ of the Dutch Copyright Act, indicated by the "Taverne" license above, 


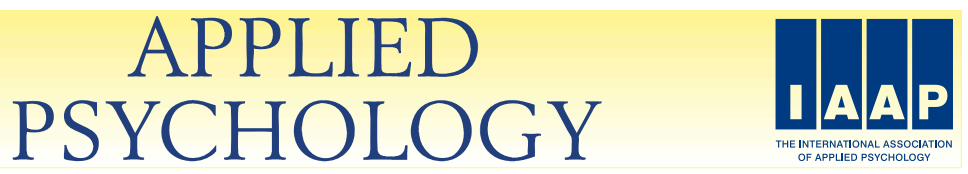

APPLIED PSYCHOLOGY: AN INTERNATIONAL REVIEW, 2010, 59 (4), 674-700 doi: $10.1111 /$ j.1464-0597.2010.00422.x

\title{
Core Self-Evaluations in Germany: Validation of a German Measure and its Relationships with Career Success
}

\author{
Thorsten Stumpp* and Peter M. Muck \\ Bielefeld University, Germany \\ Ute R. Hülsheger \\ Maastricht University, The Netherlands \\ Timothy A. Judge \\ University of Florida, USA \\ Günter W. Maier \\ Bielefeld University, Germany
}

\begin{abstract}
The present study reports the results of a validation of a German version of the Core Self-Evaluations Scale (CSES) and its relationships with career success. Data were collected in three occupational samples to address various aspects of validation. Our results confirm the proposed one-factor structure of the scale as well as convergent, discriminant, criterion, and predictive validity. Furthermore, the German CSES shows incremental validity over the individual core traits (neuroticism, self-esteem, self-efficacy, and locus of control), the Big Five, and positive and negative affect. Thus, the German version of the Core Self-Evaluations Scale is a reliable, valid, and economic measure for both research and practical applications. Furthermore, hypothesised relationships of core self-evaluations with objective as well as subjective career success were confirmed. Possible explanations of these relationships are discussed.
\end{abstract}

On présente dans cet article une étude de validation d'une version allemande de la Core Self-Evaluation Scale (CSES) avec son rapport au succès professionnel. Les données ont été recueillies auprès d'échantillons relevant de trois métiers pour couvrir plusieurs aspects de la validation. Nos résultats confirment la structure unifactorielle attendue ainsi que les validités convergente, discrimi-

* Address for correspondence: Thorsten Stumpp, Department of Psychology—Work and Organizational Psychology, Bielefeld University, P.O. Box 1001 31, 33501 Bielefeld, Germany. Email: thorsten.stumpp@uni-bielefeld.de

We gratefully acknowledge the assistance of Miriam Kesting in collecting the data. 
nante, prédictive et critérielle. En outre, la CSES allemande présente une validité incrémentielle pour le Big Five, les émotions positives et négatives et les traits centraux individuels (névrotisme, estime de soi, auto-efficience et locus of control). La version allemande de la CSES est par conséquent un outil fidèle, valide et économique aussi bien pour la recherche que pour les applications pratiques. Sans compter qu'ont été confirmées les relations supposées des autoévaluations centrales avec le succès professionnel, qu'il soit objectif ou subjectif. On analyse les raisons possibles de ces relations.

\section{INTRODUCTION}

Personality plays an important role in work and organisational behavior (Barrick \& Mount, 2005). Not only is it related to job performance, but also to various other vocational outcomes like intention to leave, absenteeism, citizenship behavior, job satisfaction, organisational commitment, leadership effectiveness, and career success (Barrick \& Mount, 2005; Hülsheger \& Maier, 2008; Thoresen, Kaplan, Barsky, Warren, \& de Chermont, 2003). Most personality research in organisational behavior has focused on dimensions of the Big Five personality traits. However, a decade ago, Judge, Locke, and Durham (1997) introduced a higher-order personality construct - termed the core self-evaluations (CSE) - that has gained considerable attention. Core self-evaluations are a broad and fundamental personality trait that represents the conceptual and empirical overlap of four dispositional traits: neuroticism, self-esteem, self-efficacy, and internal locus of control (Judge, Erez, Bono, \& Thoresen, 2002). Research has shown that the core self-evaluations construct is related to job satisfaction and performance (Bono \& Judge, 2003) as well as other vocational criteria such as health (Best, Stapleton, \& Downey, 2005), responses to feedback (Bono \& Colbert, 2005), customer service (Salvaggio, Schneider, Nishii, Mayer, Ramesh, \& Lyon, 2007), and job search behavior (Wanberg, Glomb, Song, \& Sorensen, 2005). Thus, the measurement and inclusion of core self-evaluations in studies is of great relevance in both research and practice.

One issue involved in using CSE in research and practice is the measurement of the trait. Early CSE research measured the four core traits individually, and formed CSE from a composite of the four traits. More recently, Judge, Erez, Bono, and Thoresen (2003) developed a short scale to assess core self-evaluations economically.

The purpose of the present study was therefore to validate a German version of the Core Self-Evaluations Scale. Further, we sought to extend existing findings on the relationship between CSE and career success (e.g. Bono \& Judge, 2003; Judge \& Hurst, 2007) by investigating multiple measures of subjective and objective career success. 


\section{Core Self-Evaluations}

Conceptually, core self-evaluations are an elementary assessment of oneself and one's functioning in the world (Judge et al., 1997; Judge, Erez, \& Bono, 1998). Drawing from diverse literatures (philosophy, clinical psychology research and practice, job satisfaction research, stress research, child development theory, personality theory, and social psychology), Judge and colleagues introduced the concept of core evaluations as an integrating principle for understanding the personological bases of job satisfaction. In this initial formulation they searched the literature for traits that met three criteria: self-evaluation (evaluations of the self as opposed to description of oneself or others), fundamentality (evaluations related to the core of the self, i.e. source traits as opposed to surface traits), and scope (evaluations of broad personality dimensions [cardinal traits] instead of narrow personality dimensions). Subsequently, four traits (self-esteem, generalised self-efficacy, neuroticism [reverse-coded], and locus of control) were identified. These share important commonalities in that seeing oneself as successful and worthy (= self-esteem), trusting in one's capabilities of performing in many contexts (= self-efficacy), and believing in one's ability to control one's environment (= locus of control) are self-evaluations that strongly overlap (Bono \& Judge, 2003). Individuals with high core self-evaluations thus have a positive self-appraisal (high self-esteem), believe in their own performance capacity (high selfefficacy), have a positive view of the world as well as a low tendency to focus on negative aspects of the self (low neuroticism), and believe they have control over events in their life (high internal locus of control).

Apart from the conceptual overlap, the four core traits have also been shown to be empirically related: Meta-analytic evidence confirmed substantial intercorrelations between the underlying core traits (Judge et al., 2002) and confirmatory and exploratory factor analytic studies revealed that one common factor underlies the four core traits (Erez \& Judge, 2001; Judge, Bono, \& Locke, 2000; Judge, Locke, Durham, \& Kluger, 1998). Discriminant validity was further established by showing moderate correlations with the Big Five traits extraversion and conscientiousness, and relatively weak correlations with openness and agreeableness (Judge et al., 2002).

In their seminal paper, Judge et al. (1997) argued that core self-evaluations should be related to job satisfaction and performance. These relationships have subsequently been demonstrated in several studies (for an overview see Bono \& Judge, 2003). With regard to job performance, Judge and Bono (2001) reported a validity of .19-.26-a value comparable to Barrick, Mount, and Judge's (2001) estimate of the validity of conscientiousness. In terms of job satisfaction, Judge and colleagues (Judge \& Bono, 2001; Judge, Bono, Erez, \& Locke, 2005; Judge et al., 2000; Judge et al., 1998) found moderate to strong relationships (correlations between .17 and .51), which has led to the conclu- 
sion that core self-evaluations may be the best dispositional predictor of job satisfaction (Judge, Heller, \& Klinger, 2008; Judge, Van Vianen, \& De Pater, 2004).

In analysing the process by which core self-evaluations affect job satisfaction, Judge and colleagues presented three possible mediating mechanisms: First, core self-evaluations facilitate the attainment of complex jobs. Second, individuals with high core self-evaluations perceive their job as being more intrinsically fulfilling (Judge et al., 2000; Judge et al., 1998). Third, employees with high core self-evaluations tend to choose work goals that are consistent with their intrinsic values which, in turn, enhances their job satisfaction (Judge et al., 2005).

None of the above-mentioned studies used a direct measure of core selfevaluations. Usually, one measure is used for each of the four core traits, respectively. The four scales are then either analysed separately or they are treated as indicators of a higher-order CSE construct. To assess core selfevaluations directly and economically, Judge et al. (2003) developed the Core Self-Evaluations Scale (CSES), a parsimonious measure consisting of 12 items. These items cover the content domains of the constituent core traits. This scale showed the assumed one-factor structure and demonstrated good reliability (internal consistency $\alpha=.84$; test-retest $r=.81$ ). With regard to convergent and discriminant validity, the scale revealed strong correlations with the core traits, moderate correlations with extraversion and conscientiousness, and non-significant correlations with openness and agreeableness. The scale displayed strong relationships with job performance and satisfaction, even above the core traits and the remaining Big Five traits. Used in subsequent research (e.g. Beal, Trougakos, Weiss, \& Green, 2006; Laschinger, Purdy, \& Almost, 2007; Nikolaou \& Judge, 2007; Wanberg et al., 2005), the scale's properties have continued to be supported.

\section{Core Self-Evaluations and Career Success}

Career success can be defined as "positive psychological or work related outcomes or achievements one has accumulated as a result of one's work experiences" (Judge, Cable, Boudreau, \& Bretz, 1995, p. 486). It contains both subjective (intrinsic) and objective (extrinsic) aspects. Subjective career success is defined as an individual's reactions and attitudes with regard to his or her work and career. Job satisfaction and career satisfaction are subjective reactions to one's career and therefore form distinct indicators of subjective career success (Judge, Higgins, Thoresen, \& Barrick, 1999). In contrast, income and ascendancy (e.g. number of promotions) are observable and objectively measurable outcomes and therefore form indicators of objective career success.

Studies that have investigated the relationship between CSE and career success up until now have been fragmentary and focused primarily on job

(C) 2010 The Authors. Applied Psychology: An International Review (C) 2010 International Association of Applied Psychology. 
satisfaction (see Bono \& Judge, 2003, for an overview). We want to argue that it is timely to build upon these studies and extend the investigation of the CSE-career success relationship to additional indicators of career success. There are two main reasons why the relation between CSE and career success should be further elaborated. First, a comprehensive study of the relation between CSE and various career success criteria broadens the evidence for criterion validity of CSE. Second, there is a need to extend the hitherto sparse findings on the relation between personality constructs and career success (e.g. Kilduff \& Day, 1994; Tokar, Fischer, \& Subich, 1998; Boudreau, Boswell, \& Judge, 2001; Seibert, Crant, \& Kraimer, 1999; Seibert \& Kraimer, 2001; Dilchert \& Ones, 2008). Unlike the moderate relations between personality traits and job performance (cf. Hülsheger \& Maier, 2008), there is evidence (e.g. Judge et al., 1999) that the effects of personality accumulate over time and that the influence of personality is substantial in the long run (cf. Barrick \& Mount, 2005). Consequently, CSE is a likely candidate to show substantial relationships with career success.

Why is it important to broaden the range of indicators of objective and subjective success in investigating the link between CSE and career success? Conceptually subjective and objective career success criteria are regarded as positively related yet empirically distinct. Meta-analytic findings show, for instance, that the correlations between objective career success criteria and career satisfaction are only low to moderate (corrected correlations varied between .22 and .30; Ng, Eby, Sorensen, \& Feldman, 2005). Further, objective career success criteria only correlate weakly with each other: $\mathrm{Ng}$ et al. (2005) found only approximately 3 per cent of shared variance between income and number of promotions. This shows that both variables are distinct aspects of objective career success. For subjective career success criteria (career satisfaction and job satisfaction), the positive relation is somewhat higher. Yet, these satisfaction constructs still share less than 25 per cent of their variance (e.g. Judge et al., 1995; Boudreau et al., 2001). Given these conceptual and empirical differences among career success criteria it is important to include various indicators of career success to cover the construct comprehensively. Consequently, multiple criteria of both subjective (job satisfaction and career satisfaction) and objective career success (income and number of promotions) will be considered in the present study.

Research conducted in personality and in IO psychology suggests positive links between CSE and indicators of career success. Extant research that has examined the dispositional basis of career success has mainly considered the Big Five (e.g. Boudreau et al., 2001; Hülsheger, Specht, \& Spinath, 2006; Seibert \& Kraimer, 2001). Since one of the Big Five traits (neuroticism) is also one of the core traits, this research gives important insights into the relationship between CSE and career success. These studies have shown consistently that neuroticism displays negative correlations with subjective career success.

(C) 2010 The Authors. Applied Psychology: An International Review (C) 2010 International Association of Applied Psychology. 
Further, there is meta-analytic evidence (Ng et al., 2005) of moderate to strong relationships between two of the core traits (neuroticism and locus of control) and subjective career success. With regard to objective career success, neuroticism was negatively related to both income and promotion while locus of control was positively related to income. Recently, Judge and Hurst (2007) have shown that individuals with high core self-evaluations in adolescence and young adulthood capitalise on their early advantages and achieve higher career outcomes later in life. This was evidenced by positive relationships between core self-evaluations on the one hand and income, socioeconomic status, and academic achievement on the other. Taken together, these studies suggest that a positive relationship between CSE and objective and subjective indicators of career success can be expected.

\section{The Present Study}

In sum, our study follows two concerns: First, we present the validation of a German version of the Core Self-Evaluations Scale and thereby test the cross-cultural generalisability of the measure (cf. Van de Vijver \& Hambleton, 1996). Second, we investigate the validity of CSE regarding various indicators of career success.

With regard to our first purpose, we follow the procedures Judge and colleagues (2003) used in validating the original CSE scale. First, we test the hypothesised one-factor structure and compare it with a four-factor model. Second, we investigate the test-retest reliability as well as the convergent and discriminant validity of the scale. Third, criterion validity will be examined with regard to job and life satisfaction. We will further extend the criterion domain to organisational commitment, which has not been investigated with regard to CSE until now. Next to job satisfaction, organisational commitment is perhaps the most widely studied job attitude in industrial and organisational psychology (Mathieu \& Zajac, 1990). Research on the relationship between individual core traits (neuroticism, self-efficacy, and locus of control) and organisational commitment suggests a positive relationship between CSE and organisational commitment (Mathieu \& Zajac, 1990; Ng, Sorensen, \& Eby, 2006; Thoresen et al., 2003). In one sample we investigate concurrent relationships between CSE and these criteria while we focus on longitudinal relationships in another sample. Fourth and finally, we investigate the incremental validity of CSE above the core traits, above the remaining Big Five traits, and above positive and negative affectivity with regard to life and job satisfaction. By analysing the incremental validity of CSE over the four core traits and simultaneously controlling for the remaining Big Five traits we can corroborate Judge and colleagues' (2003) assumption that it is not variance shared with the Big Five that accounts for the incremental validity of CSE over the four core traits. Controlling for positive and nega-

(C) 2010 The Authors. Applied Psychology: An International Review (C) 2010 International Association of Applied Psychology. 
tive affectivity further allows us to replicate international findings showing that CSE displays incremental validity over positive and negative affectivity (Judge et al., 1998; Piccolo, Judge, Takahashi, Watanabe, \& Locke, 2005). Given that positive and negative affectivity is related to job and life satisfaction (Judge \& Larsen, 2001), this is a crucial step in establishing the validity of CSE.

Our hypotheses can be summed up as follows:

Hypothesis 1.1 (Factor structure): The German Core Self-Evaluations Scale represents a one-factor structure (the fit is not significantly worse than the fit of a four-factor structure).

Hypothesis 1.2 (Convergent validity): The German Core Self-Evaluations Scale exhibits significant positive relationships with three of the four individual core traits (self-esteem, generalised self-efficacy, locus of control) and significant negative relationships with neuroticism.

Hypothesis 1.3 (Discriminant validity): The correlations between the German Core Self-Evaluations Scale and the individual core traits are higher than the correlations between the German Core Self-Evaluations Scale and the other traits distinct from CSE (the remaining Big Five traits and positive and negative affectivity).

\section{Hypothesis 1.4 (Criterion validity):}

Hypothesis 1.4a (Concurrent validity): The German Core Self-Evaluations Scale exhibits significant positive relationships with job and life satisfaction as well as with organisational commitment.

Hypothesis 1.4b (Predictive validity): The German Core Self-Evaluations Scale completed before job entry exhibits significant positive relationships with job and life satisfaction as well as with organisational commitment after job entry.

Hypothesis 1.5 (Incremental validity): The German Core Self-Evaluations Scale demonstrates incremental validity above the individual core traits, above the remaining Big Five traits, and above dispositional positive and negative affect (positive and negative affectivity) for all criteria.

The second purpose of our study is to further examine the relationship of core self-evaluations and career success. To assess career success comprehensively, different indicators of both subjective (job satisfaction and career satisfaction) and objective career success (income and number of promotions) are taken into account. By including career satisfaction and number of promotions, we extend previous research on CSE which has relied predominantly on job satisfaction and income. 
Hypothesis 2.1: Core self-evaluations exhibit significant positive relationships with objective career success (income and number of promotions).

Hypothesis 2.2: Core self-evaluations exhibit significant positive relationships with subjective career success (job and career satisfaction).

\section{METHOD}

\section{Samples and Participants}

To collect the data and to help obtain data with variance in the predictors as well as in the criteria, we used online questionnaires. Using a "snowball procedure" we sent an e-mail including the link to the online questionnaire and asked the receiver to answer the questionnaire as well as to forward the e-mail to people they knew. The data were collected in three different occupational samples: In the first sample, we collected data on stability (testretest reliability) of the German CSES and its relationship with career success. The second sample allowed us to further investigate the criterionrelated validity and assess the incremental validity of the German CSES over the individual core and other dispositional traits. The third sample-job newcomers - allowed us to test the criterion-related validity of the German CSES in a study where CSE and the criteria were measured at different time points.

Sample 1. Sample 1 consisted of 158 full-time employees working for different organisations. The mean age was 31.57 years $(S D=8.64$ years $)$ and there were slightly more women $(89 ; 56 \%)$ than men. Sixty-six $(42 \%)$ participants had a university diploma as highest vocational qualification, and 38 (24\%) had an apprenticeship. Most participants were employees of organisations in the public service sector $(41 ; 26 \%)$, followed by health care $(27$; $17 \%$ ) and services $(19 ; 12 \%)$. The data were collected at two measurement points: At time 1 core self-evaluations and indicators of objective (salary and number of promotions) and subjective (job and career satisfaction) career success were assessed. At time 2-after approximately 2 months - core selfevaluations were assessed again. As 206 participants completed the time 1 questionnaire the response rate was 76.7 per cent.

Sample 2. Sample 2 comprised 199 employees from different organisations. Their ages ranged from 20 to 64 years, with an average of 38.8 years $(S D=9.0$ years $)$. As in Sample 1 , there were slightly more women $(113 ; 57 \%)$ than men in the sample. Of the participants, $114(57 \%)$ had an apprenticeship and $73(37 \%)$ had a university diploma as their highest vocational qualification, and $11(6 \%)$ had no vocational qualification at all. Participants were 
employed in different companies and branches, mostly in health care (38; $19 \%)$, in heavy industry $(32 ; 16 \%)$, and in the service sector $(27 ; 14 \%)$.

Sample 3. Sample 3 consisted of 118 job newcomers who had started their jobs in different organisations. Their mean age was 16.68 years $(S D=1.12$ years) and, again, there were somewhat more women $(65 ; 55 \%)$ than men in the sample. The job newcomers started their apprenticeships for diverse jobs (e.g. banker, industrial mechanic) in organisations from different branches, mainly in public service $(76 ; 64 \%)$ and manufacturing $(33 ; 28 \%)$. We used the following design to predict job satisfaction and organisational commitment: At time 1 , we assessed core self-evaluations while the job newcomers were still at school. At time 2, we assessed job satisfaction and organisational commitment as well as life satisfaction. At time 2, the job newcomers had been working in their jobs for an average of 4 months. As 220 participants completed the time 1 questionnaire, the response rate was 53.6 per cent.

\section{Measures}

Core Self-Evaluations. The core self-evaluations were measured with a German translation of the Core Self-Evaluations Scale that was used with all three samples. First, we translated the items into German. Afterwards, the items were back-translated into English by a bilingual expert, and then compared with the original version and adjusted accordingly. The scale consists of 12 items with a response scale ranging from 1 (strongly disagree) to 5 (strongly agree). The original as well as the translated items are displayed in the Appendix.

Criteria. Life satisfaction was measured with a German version (Maier, 2001) of the Satisfaction with Life Scale (Diener, Emmons, Larsen, \& Griffin, 1985). The scale consists of five items ranging from 1 (strongly disagree) to 5 (strongly agree) and was assessed in Samples 2 and 3. To measure job satisfaction, we used the short version of the Job Description Form (Neuberger \& Allerbeck, 1978), a German questionnaire that assesses various facets of job satisfaction (i.e. relationship with colleagues, relationship with supervisor, job in general, work conditions, organisation and management, promotion opportunities, and payment) and consists of seven items. The response scale ranged from 1 (strongly disagree) to 7 (strongly agree). We measured job satisfaction in all three samples. Affective organisational commitment was measured in Samples 2 and 3. In Sample 1, it was measured with the German version (Maier \& Woschée, 2002) of the nine-item short form of the Organisational Commitment Questionnaire (Porter \& Smith, 1970). In Sample 3, it was assessed with the German version (Schmidt, Hollmann, \& Sodenkamp, 1998) of the commitment questionnaire of Allen and Meyer (1990). This 
scale consists of eight items. Both scales ranged from 1 (strongly disagree) to 5 (strongly agree). Career satisfaction was measured in Sample 1. It was assessed with a German translation of the five-item questionnaire of Greenhaus, Parasuraman, and Wormley (1990). The response scale ranged from 1 (strongly disagree) to 5 (strongly agree). We also assessed objective career success in Sample 1. We used the indicators suggested by Judge and colleagues (Judge, et al., 1995; Judge et al., 1999): salary and number of promotions. Monthly income was measured in categories ranging from "below 1,000 Euro" to a maximum of "more than 7,000 Euro" in steps of 500 Euro. Number of promotions was assessed directly by asking the participants to report their number of promotions. Both salary and number of promotions were assessed via self-report.

Individual Core Traits. All individual core traits were assessed in Sample 2 only. The German version (Borkenau \& Ostendorf, 1993) of the NEO-FFI personality inventory (Costa \& McCrae, 1992) was used to assess the Big Five trait neuroticism. It is measured with 12 items. To assess self-esteem, the participants completed the German version (von Collani \& Herzberg, 2003) of Rosenberg's 10-item self-esteem scale (Rosenberg, 1965). Generalised selfefficacy was assessed with the German 10-item inventory of Schwarzer and Jerusalem (1999). These three inventories had response scales from 1 (strongly disagree) to 5 (strongly agree). To assess locus of control, we used the eight-item internality subscale of the German locus of control questionnaire (Krampen, 1991; cf. Levenson, 1981). The response scale ranged from 1 (strongly disagree) to 6 (strongly agree).

Other Traits. The remaining Big Five traits, extraversion, conscientiousness, openness, and agreeableness, were also assessed with the German NEOFFI personality inventory, each measured with 12 items. For positive and negative affectivity, we used the German version (Krohne, Egloff, Kohlmann, \& Tausch, 1996) of the Positive and Negative Affect Schedule (PANAS; Watson, Clark, \& Tellegen, 1988). We asked participants to indicate how they feel at work in general and measured each affective disposition with 10 items on a scale ranging from 1 (strongly disagree) to 5 (strongly agree). All these other traits were assessed in Sample 2 only.

The reliability of all criteria and traits measured by Cronbach's alpha was at least satisfactory (see Tables 2-4 for Samples 1-3). All reliabilities exceeded values of .70 .

\section{Analysis}

To examine the factor structure of the translated scale we used confirmatory factor analysis conducted with AMOS 6 (Arbuckle, 2006). We applied a

(C) 2010 The Authors. Applied Psychology: An International Review (C) 2010 International Association of Applied Psychology. 
maximum likelihood estimation method and tested for multivariate normality. Although all of the items had skewness and kurtosis values that were within the bounds defined by West, Finch, and Curran (1995), the data did not conform to multivariate normality (Mardia test; Mardia, 1985; all three critical ratios $7 ; p<.001)$. Therefore, we used the Bollen-Stine bootstrap method (Bollen \& Stine, 1992; 1,000 bootstrap samples) to correct the $p$-values for the chi-square test.

Consistent with Bollen (1989), we report various fit indices: chi-square $\left(\chi^{2}\right)$, goodness of fit index (GFI), comparative fit index (CFI), Tucker-Lewis index (TLI), and the root mean square error of approximation (RMSEA).

Because all 12 items of the Core Self-Evaluations Scale are supposed to represent one common factor, in the hypothesised one-factor model all items loaded on one latent factor. In the alternative model, all items representing one of the four specific factors loaded on their particular factor (e.g. the three items focusing self-esteem on a self-esteem factor, the three items focusing self-efficacy on a self-efficacy factor). Since these models are nested, we used the chi-square difference $\left(\Delta \chi^{2}\right)$ to compare the models (Bollen, 1989). We accepted the more parsimonious model if it was not significantly different from a more complex model.

To assess the nomological network, another aspect of construct validity, we analysed convergent and discriminant validity. Convergent validity exists if a measure is highly correlated with construct-related measures. This can be assessed by the correlation of the Core Self-Evaluations Scale with the four core traits, i.e. neuroticism, self-esteem, self-efficacy, and locus of control. To show discriminant validity, a measure has to be distinct from construct-unrelated measures. To investigate discriminant validity, core self-evaluations should correlate more strongly with the four individual core traits than with other traits such as extraversion, conscientiousness, openness, and agreeableness, as well as positive and negative affectivity. We used the procedure presented by Meng, Rosenthal, and Rubin (1992) to compare correlated correlation coefficients. Criterion validity was assessed using hierarchical regression analysis. We controlled for age, gender, and industry in all regression analyses. Industry was dummy-coded separately for each sample. In Sample 1, participants were from 15 different industries; in Sample 2, they were from 12 different industries; and in Sample 3, they were from four different industries.

\section{RESULTS}

\section{Construct Validity of German CSES}

Three confirmatory factor analyses were conducted, for each sample respectively. The fit indices for the one- and the four-factor solutions as well as the 
model comparison statistics are presented in Table 1. Fit statistics for the one-factor model in each sample are acceptable, and the one-factor models are not significantly different from the four-factor models within each sample. Furthermore, the fit indices of our one-factor models are comparable to the results for the original scale (one-factor model of the original study: GFI: .88-.94; CFI: .87-.93; RMSEA: .06-.10; Judge et al., 2003). Thus, our results support the one-factor structure of the German version of the CSES. Hypothesis 1.1 is therefore supported.

Descriptive statistics, reliabilities, and correlations of all study variables for all samples are displayed in Tables 2, 3, and 4. The psychometric properties of the translated scale are good. The internal consistency reliabilities (Cronbach's alpha) were $\alpha=.86$ for Sample 1 (Time 1 as well as Time 2), $\alpha=.83$ for Sample 2, and $\alpha=.81$ for Sample 3. Test-retest reliability was .82 (Sample 1). These results further support the construct validity of the German version of the Core Self-Evaluations Scale.

To assess convergent validity we examined the correlations of core selfevaluations with the four core traits. These correlations are displayed in Table 3. As expected, the correlations of core self-evaluations with the core traits are strong. Only locus of control correlated less strongly with core self-evaluations. In sum, these correlations largely support the convergent validity of the translated scale and thus Hypothesis 1.2. With regard to discriminant validity, we statistically compared the correlations between core self-evaluations and the core traits with correlations between core selfevaluations and the other traits using the test by Meng et al. (1992). Results shown in Table 5 support the assumption that the correlation between core self-evaluations and the core traits is higher than between core selfevaluations and the traits distinct from CSE. As with the original scale (Judge et al., 2003), the Core Self-Evaluations Scale did not correlate more highly with locus of control than with the other traits. All in all, the overall results support discriminant validity for the Core Self-Evaluations Scale. Hypothesis 1.3 is mostly supported.

\section{Criterion and Incremental Validity}

To assess the criterion and incremental validity of the measure, we used three samples to investigate different aspects. The German version of the Core Self-Evaluations Scale had significant correlations with all criteria (job satisfaction, life satisfaction, and organisational commitment) across all samples, as can be seen from Tables 2,3, and 4. The second sample allowed us to have a closer look not only at the criterion validity but also at the incremental validity over the core traits as well as over other traits distinct from CSE like the remaining Big Five traits as well as positive and negative affectivity. The results concerning job satisfaction, organisational commitment, and life

(C) 2010 The Authors. Applied Psychology: An International Review (C) 2010 International Association of Applied Psychology. 


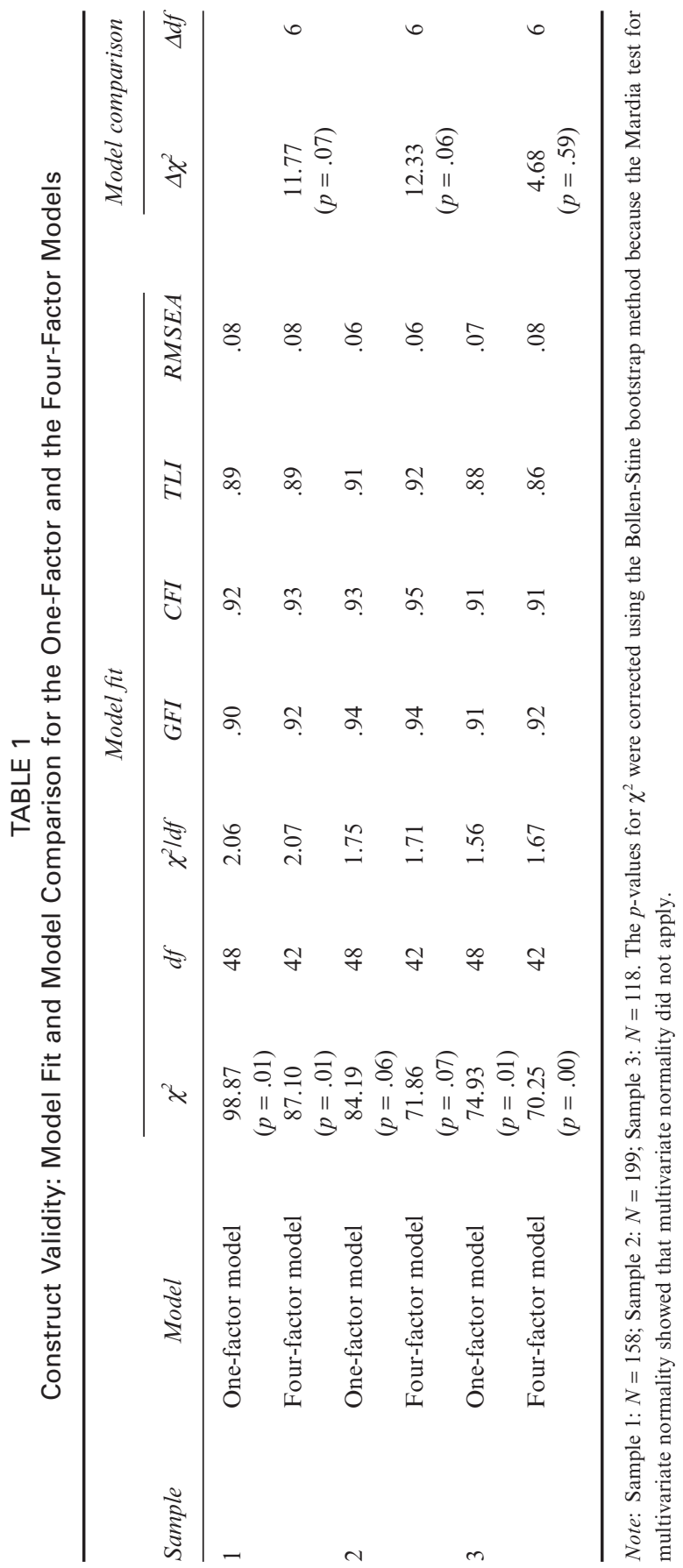


TABLE 2

Descriptive Statistics, Scale Reliabilities, and Correlations for Sample 1

\begin{tabular}{|c|c|c|c|c|c|c|c|c|c|}
\hline & Variable & $\mathrm{M}$ & $\mathrm{SD}$ & 1 & 2 & 3 & 4 & 5 & 6 \\
\hline 1 & Core self-evaluations $\mathrm{T} 1$ & 3.88 & .55 & .87 & & & & & \\
\hline 2 & Core self-evaluations $\mathrm{T} 2$ & 3.87 & .50 & .82 & .86 & & & & \\
\hline 3 & Income & - & - & .28 & .11 & - & & & \\
\hline 4 & Number of promotions & 1.13 & 2.46 & .24 & .08 & .38 & - & & \\
\hline 5 & Job satisfaction & 5.17 & 1.03 & .37 & .29 & .05 & .08 & .82 & \\
\hline 6 & Career satisfaction & 3.64 & .77 & .42 & .32 & .21 & .26 & .67 & .86 \\
\hline
\end{tabular}

Note: $N=158$. Scale Reliabilities (Coefficient alpha) are on the diagonal in italics. $r \mathrm{~s}>|.16|, p<.05 ; r \mathrm{~s} \geq|.20|$, $p<.01 ; r \mathrm{~s} \geq|.25|, p<.001$.

satisfaction are presented in Table 6. With regard to all three criteria, the German Core Self-Evaluations Scale explained a small incremental amount of variance $(1-5 \%)$ above the core traits, the remaining Big Five traits, as well as dispositional affectivity. Thus, Hypotheses 1.4a and 1.5 are supported.

As this sample only allows for a cross-sectional investigation of the criterion validity, we tested the predictive validity in the third sample. The same criteria were used as in Sample 2. The results are displayed in Table 7. As can be seen, the Core Self-Evaluations Scale completed before job entry explained small to moderate amounts of variance in job satisfaction $(5 \%)$, organisational commitment $(10 \%)$, and life satisfaction (18\%) approximately 4 months after job entry, supporting Hypothesis 1.4b.

\section{Core Self-Evaluations and Career Success}

In the first sample, we conducted hierarchical regressions of objective (income and number of promotions) and subjective (job and career satisfaction) career success on core self-evaluations statistically controlling for age, gender, tenure, level of education, and industry (see Table 8). The results reveal that the Core Self-Evaluations Scale is related to objective as well as subjective career success. The incremental amount of variance accounted for is 3-4 per cent for the objective career success measures and 15-18 per cent for the subjective career success measures. Therefore, Hypotheses 2.1 and 2.2 are supported. However, as can be seen in Table 2, in contrast to CSE measured at T1 CSE measured at T2 does not relate to the objective career success criteria income and number of promotions and its relation to the subjective career success criteria is diminished. All these differences in the correlations between CSE measured at $\mathrm{T} 1$ and the criteria measured at $\mathrm{T} 1$ compared to the correlations between CSE measured at T2 and the criteria measured at T1 are significant according to the test proposed by Meng et al. (1992) except for job satisfaction (income: $Z=3.60, p<.001$; number of promotions: $Z=3.37$, 


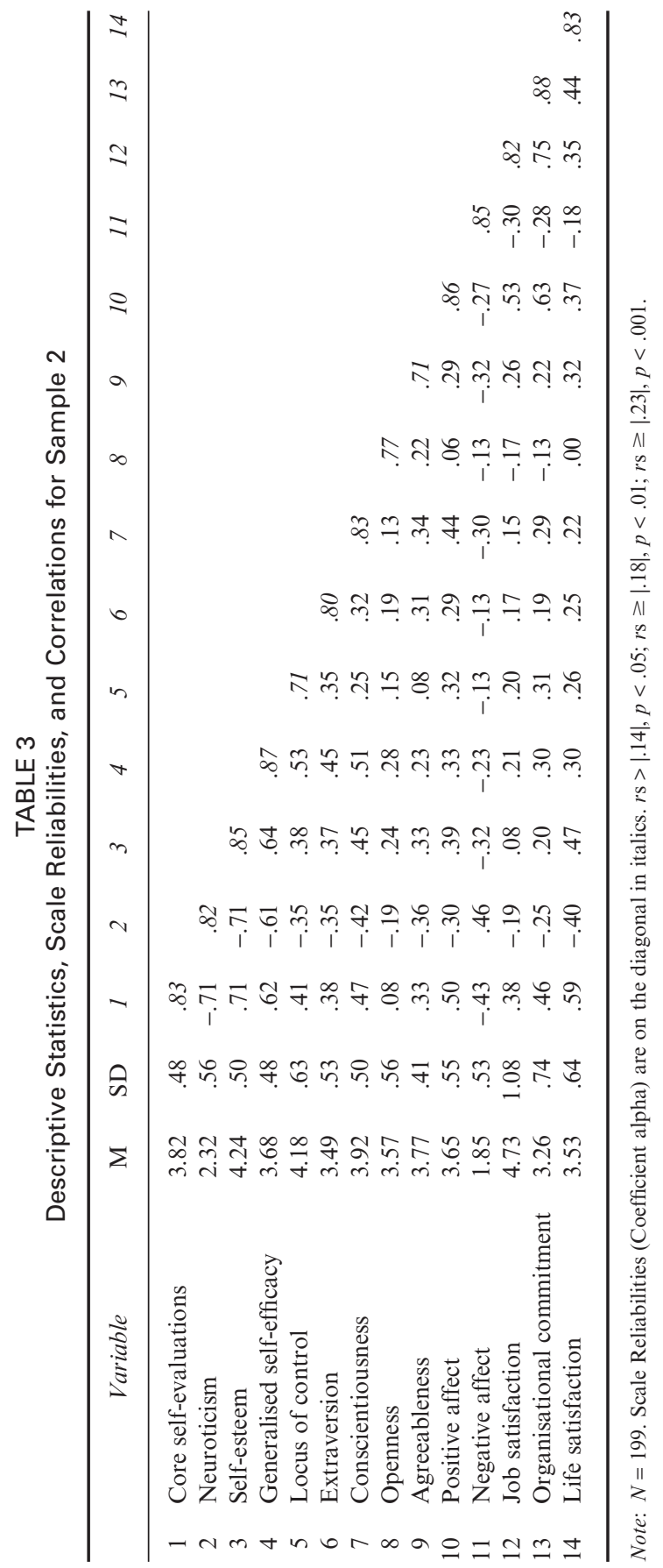

(C) 2010 The Authors. Applied Psychology: An International Review (C) 2010 International Association of Applied Psychology. 
TABLE 4

Descriptive Statistics, Scale Reliabilities, and Correlations for Sample 3

\begin{tabular}{|c|c|c|c|c|c|c|c|}
\hline & Variable & M & $\mathrm{SD}$ & 1 & 2 & 3 & 4 \\
\hline 1 & Core self-evaluations $\mathrm{T} 1$ & 3.65 & .52 & .81 & & & \\
\hline 2 & Job satisfaction $\mathrm{T} 2$ & 5.62 & .99 & .23 & .85 & & \\
\hline 3 & Organisational commitment $\mathrm{T} 2$ & 3.51 & .69 & .32 & .67 & .76 & \\
\hline 4 & Life satisfaction $\mathrm{T} 2$ & 3.53 & .82 & .43 & .41 & .32 & .88 \\
\hline
\end{tabular}

Note: $N=118$. Scale Reliabilities (Coefficient alpha) are on the diagonal in italics. $r \mathrm{~s}>|.18|, p<.05 ; r \mathrm{~s} \geq|.23|$, $p<.01 ; r \mathrm{~s} \geq|.29|, p<.001$.

TABLE 5

Convergent and Discriminant Validity: Correlations and Correlation Comparison

\begin{tabular}{lcccc}
\hline Correlation comparison & $\mathrm{r}_{y x l}$ & $\mathrm{r}_{y \times 2}$ & $\mathrm{r}_{x l x 2}$ & $\mathrm{Z}^{a}$ \\
\hline CSE-N vs. CSE-E & -.71 & .38 & -.35 & $5.35^{* * *}$ \\
CSE-N vs. CSE-O & -.71 & .08 & -.19 & $8.25^{* * *}$ \\
CSE-N vs. CSE-A & -.71 & .33 & -.36 & $6.05^{* * *}$ \\
CSE-N vs. CSE-C & -.71 & .47 & -.42 & $4.28^{* * *}$ \\
CSE-N vs. CSE-PA & -.71 & .50 & -.30 & $3.55^{* * *}$ \\
CSE-N vs. CSE-NA & -.71 & -.43 & .46 & $5.03^{* * *}$ \\
CSE-SES vs. CSE-E & .71 & .38 & .38 & $5.46^{* * *}$ \\
CSE-SES vs. CSE-O & .71 & .08 & .24 & $8.48^{* * *}$ \\
CSE-SES vs. CSE-A & .71 & .33 & .33 & $5.94^{* * *}$ \\
CSE-SES vs. CSE-C & .71 & .47 & .45 & $4.38^{* * *}$ \\
CSE-SES vs. CSE-PA & .71 & .50 & .39 & $3.74^{* * *}$ \\
CSE-SES vs. CSE-NA & .71 & -.43 & -.32 & $4.58^{* * *}$ \\
CSE-SEF vs. CSE-E & .62 & .38 & .46 & $3.95^{* * *}$ \\
CSE-SEF vs. CSE-O & .62 & .08 & .28 & $7.06^{* * *}$ \\
CSE-SEF vs. CSE-A & .62 & .33 & .24 & $4.28^{* * *}$ \\
CSE-SEF vs. CSE-C & .62 & .47 & .51 & $2.68^{* *}$ \\
CSE-SEF vs. CSE-PA & .62 & .50 & .33 & 1.91 \\
CSE-SEF vs. CSE-NA & .62 & -.43 & -.23 & $2.75^{* *}$ \\
CSE-LOC vs. CSE-E & .41 & .38 & .35 & 0.41 \\
CSE-LOC vs. CSE-O & .41 & .08 & .15 & $3.72^{* * *}$ \\
CSE-LOC vs. CSE-A & .41 & .33 & .08 & 0.92 \\
CSE-LOC vs. CSE-C & .41 & .47 & .25 & -0.80 \\
CSE-LOC vs. CSE-PA & .41 & .50 & .32 & -1.27 \\
CSE-LOC vs. CSE-NA & .41 & -.43 & -.13 & -0.25 \\
\hline
\end{tabular}

Note: $N=199$, Sample 2. CSE = core self-evaluations, $\mathrm{N}=$ neuroticism, $\mathrm{SES}=$ self-esteem, $\mathrm{SEF}=$ self-efficacy, LOC $=$ locus of control, $\mathrm{E}=$ extraversion, $\mathrm{O}=$ openness, $\mathrm{A}=$ agreeableness, $\mathrm{C}=$ conscientiousness, $\mathrm{PA}=$ positive affect, $\mathrm{NA}=$ negative affect. $r_{\mathrm{yx} 1}=$ correlation between CSE and core trait, $r_{\mathrm{yx} 2}=$ correlation between $\mathrm{CSE}$ and the other trait distinct from CSE, $r_{\mathrm{x} 1 \times 2}=$ correlation between core and the other trait distinct from CSE. ${ }^{a}$ The $Z$-score was calculated using the absolute values of the correlations. $r \mathrm{~s}>|.14|, p<.05 ; r \mathrm{~s} \geq|.18|$, $p<.01 ; r \mathrm{~s} \geq|.23|,{ }^{* *} p<.01 ; * * * p<.001$.

(C) 2010 The Authors. Applied Psychology: An International Review (C) 2010 International Association of Applied Psychology. 
TABLE 6

Empirical Validity: Incremental Validity above Core Traits, Big Five Traits, and Positive and Negative Affect

\begin{tabular}{|c|c|c|c|c|c|c|c|}
\hline \multirow[b]{2}{*}{ Step } & \multirow[b]{2}{*}{ Variable } & \multicolumn{2}{|c|}{ Job satisfaction } & \multicolumn{2}{|c|}{ Organisational commitment } & \multicolumn{2}{|c|}{ Life satisfaction } \\
\hline & & $\Delta \mathrm{R}^{2}$ & $\beta$ & $\Delta \mathrm{R}^{2}$ & $\beta$ & $\Delta \mathrm{R}^{2}$ & $\beta$ \\
\hline 1 & Control variables ${ }^{\mathrm{a}}$ & .07 & & .06 & & .10 & \\
\hline 2 & Personality traits & $.43 * * *$ & & $.48 * * *$ & & $.32 * * *$ & \\
\hline & $\mathrm{N}$ & & .08 & & .04 & & -.02 \\
\hline & SES & & $-.29 * *$ & & -.17 & & $.25^{*}$ \\
\hline & SEF & & .17 & & .11 & & -.12 \\
\hline & LOC & & -.01 & & .12 & & .09 \\
\hline & E & & .01 & & -.04 & & -.01 \\
\hline & $\mathrm{O}$ & & $-.20 * *$ & & $-.18^{* *}$ & & -.12 \\
\hline & A & & $.16^{*}$ & & .06 & & .13 \\
\hline & $\mathrm{C}$ & & $-.19 *$ & & -.06 & & -.11 \\
\hline & PA & & $.49 * * *$ & & $.53 * * *$ & & .09 \\
\hline & NA & & $-.17 *$ & & -.11 & & .03 \\
\hline 3 & CSE & $.02 *$ & $.27 *$ & $.01^{*}$ & $.22 *$ & $.05^{* * *}$ & $.42 * * *$ \\
\hline
\end{tabular}

Note: $N=199$, Sample 2. ${ }^{\text {a }}$ Control variables: age, gender, level of education, and industry. Industry was dummy-coded. The betas are taken from the last step. ${ }^{*} p<.05 ; * * p<.01 ; * * * \quad<<.001$.

TABLE 7

Empirical Validity: Prediction of Job Attitudes and Life Satisfaction

\begin{tabular}{|c|c|c|c|c|c|c|c|}
\hline \multirow[b]{2}{*}{ Step } & \multirow[b]{2}{*}{ Variable } & \multicolumn{2}{|c|}{ Job satisfaction $T 2$} & \multicolumn{2}{|c|}{$\begin{array}{c}\text { Organisational } \\
\text { commitment } T 2\end{array}$} & \multicolumn{2}{|c|}{ Life satisfaction $T 2$} \\
\hline & & $\Delta \mathrm{R}^{2}$ & $\beta$ & $\Delta \mathrm{R}^{2}$ & $\beta$ & $\Delta \mathrm{R}^{2}$ & $\beta$ \\
\hline 1 & Control variables ${ }^{a}$ & .03 & & .05 & & .05 & \\
\hline 2 & CSE T1 & $.05^{*}$ & $.23 *$ & $.10 * * *$ & $.32 * * *$ & $.18 * * *$ & $.42 * * *$ \\
\hline
\end{tabular}

Note: $N=118$, Sample 3. ${ }^{\text {a }}$ Control variables: age, gender, and industry. Industry was dummy-coded. The betas are taken from the last step. ${ }^{*} p<.05 ; * * * p<.001$.

$p<.001$; career satisfaction: $Z=2.25, p<.05$; job satisfaction: $Z=1.77, p>.05$ ). We comment upon this finding when we discuss these results.

\section{DISCUSSION}

The first purpose of our study was to examine the validity of a German version of the Core Self-Evaluations Scale. Our results substantiate the validity of the translated scale. The one-factor structure of the scale compared to 
TABLE 8

Empirical Validity: Relation between CSE and Objective and Subjective Career Success

\begin{tabular}{|c|c|c|c|c|c|c|c|c|c|}
\hline \multirow[b]{2}{*}{ Step } & \multirow[b]{2}{*}{ Variable } & \multicolumn{2}{|c|}{ Income } & \multicolumn{2}{|c|}{$\begin{array}{l}\text { Number of } \\
\text { promotions }\end{array}$} & \multicolumn{2}{|c|}{$\begin{array}{c}\text { Job } \\
\text { satisfaction }\end{array}$} & \multicolumn{2}{|c|}{$\begin{array}{c}\text { Career } \\
\text { satisfaction }\end{array}$} \\
\hline & & $\Delta \mathrm{R}^{2}$ & $\beta$ & $\Delta \mathrm{R}^{2}$ & $\beta$ & $\Delta \mathrm{R}^{2}$ & $\beta$ & $\Delta \mathrm{R}^{2}$ & $\beta$ \\
\hline \multirow[t]{5}{*}{1} & Control variables & $.43 * * *$ & & $.47 * * *$ & & .11 & & .10 & \\
\hline & Age & & $.41 * *$ & & $.51 * * *$ & & -.04 & & -.15 \\
\hline & Gender & & .11 & & .05 & & .06 & & .03 \\
\hline & Tenure & & .13 & & .01 & & -.15 & & .15 \\
\hline & $\begin{array}{l}\text { Level of } \\
\text { education } \\
\text { Industry }^{\mathrm{a}}\end{array}$ & & $.22^{*}$ & & $-.21^{*}$ & & .04 & & .14 \\
\hline 2 & CSE & $.04 * *$ & $.22 * *$ & $.03 * *$ & $.19^{* *}$ & $.15^{* * *}$ & $.40 * * *$ & $.18 * * *$ & $.45^{* * *}$ \\
\hline
\end{tabular}

Note: $N=158$, Sample 1. ${ }^{a}$ Industry was dummy-coded. The betas are taken from the last step. ${ }^{*} p<.05$; $* * p<.01 ; * * * \quad p<.001$.

a four-factor structure was supported. This is in line with previous findings from the original US scale, as well as from the Netherlands and Spain (Judge et al., 2003; Judge et al., 2004). Furthermore, the internal consistency reliabilities for all samples are above .80 . The German version also shows good test-retest reliability across a 2-month interval. Thus, evidence supports the unitary factor structure and reliability of the German Core Self-Evaluations Scale.

Additionally, the scale demonstrated convergent validity in that the scale was substantially correlated with the individual core traits. In the original study, Judge and colleagues (2003) analysed the comparison of correlations without statistically testing for differences. This approach as evidence of convergent validity has been criticised by Schmitt (2004). Therefore, we performed such a test (Meng et al., 1992) in our study. It revealed that the correlations with three of the core traits (neuroticism, self-esteem, and selfefficacy) are significantly higher than the correlations with the other traits distinct from CSE. Only for internal locus of control are the correlations mostly of the same magnitude. This is in line with the findings by Judge and colleagues (2003) who reported stronger correlations for core self-evaluations with extraversion and conscientiousness than for core self-evaluations and locus of control. Bono and Judge (2003) refer to the role of locus in control in research on CSE as a "vexing problem" (p. S15). This problem still warrants attention (Judge, 2009). Even when correcting for unreliability, the relation between CSE and locus of control is weaker than the relation between CSE and the other three core traits (Judge et al., 2003). This is all the more astonishing as generalised self-efficacy taps into similar self-regulatory 
beliefs (Judge et al., 2005). Although locus of control (i.e. beliefs about the controllability of the environment) seems to be a consequence of generalised self-efficacy (i.e. beliefs about the ability to successfully perform actions), there might be other factors that influence the perception of an internal locus of control beyond core self-evaluations. Furthermore, it is conceivable that a work-based measure of locus of control (e.g. Spector, 1988) would yield more favorable results.

We also analysed the correlations of CSE with positive and negative affectivity and compared them to the correlations between core self-evaluations and the core traits. The omission of dispositional affect in the original study has also been a main criticism by Schmitt (2004). Again, the correlations between core self-evaluations and core traits are mostly higher than the correlations between core self-evaluations and dispositional affect. Thus, our rigorous test of convergent validity mainly shows the same findings as in previous studies and mostly supports convergent validity. Further support for criterion validity was provided by the strong relationships between core self-evaluations and job satisfaction, organisational commitment, and life satisfaction across all samples. The translated scale had incremental validity over and above the core traits, the remaining Big Five traits, and positive and negative affectivity. Finally, the German version of the Core Self-Evaluations Scale showed predictive validity regarding job satisfaction, organisational commitment, and life satisfaction across a 4-month interval. Considering these findings together, the translated scale exhibits the intended factor structure, meets the necessary psychometric properties, shows convergent and discriminant validity, demonstrates relationships with focal vocational criteria even over and above constitutive and other traits distinct from CSE, and predicts the criteria even when these are measured several months later.

A question already raised is: Why is the Core Self-Evaluations Scale related to criteria such as job and life satisfaction and organisational commitment, over and above the core traits and additionally the Big Five traits and dispositional affectivity? Judge and colleagues (2003) proposed two explanations: First, the Core Self-Evaluations Scale measures more than just core self-evaluations. However, further trait aspects would have to be outside the Big Five context as well as outside the trait affectivity context because incremental validity over and above all of these traits has been shown in our study. We therefore conclude that this explanation by Judge and colleagues does not hold for our data. Judge et al. assumed the same because CSE did not reflect other Big Five traits any more than do typical measures of the core traits. Our approach was more direct because we controlled for the Big Five traits, the affectivity traits, and the core traits simultaneously and more directly in a hierarchical regression. Second, Judge and colleagues proposed that the Core Self-Evaluations Scale assesses the core self-evaluations more directly and thus eliminates specific factor variance attributable to the core 
traits. In this perspective, the CSE scale measures the common core of the four core traits more directly and with less error than the individual core traits. Our study adds some support to the second explanation as incremental validity could not only be shown for the Big Five but at the same time even for two more theoretically related traits (i.e. positive and negative affectivity).

As our results support the validity of the German translation of the Core Self-Evaluations Scale, the study further contributes to the generalisation of the core self-evaluations construct. Thus, our results from three German samples provide further evidence for the universality of the scale and for the cross-cultural generalisability of the core self-evaluations construct. Furthermore, core self-evaluations also exhibit a relation with organisational commitment, another important job attitude.

The second focus of our study was on the relationship of CSE with career success. Our findings reveal that core self-evaluations are related to different indicators of subjective as well as objective career success. Individuals who see themselves in a positive manner are not only more satisfied with their jobs and their careers, but they also report higher monthly income and more promotions. Although $\mathrm{Ng}$ and colleagues (2005) point out the conceptual distinctiveness between objective and subjective career success, it is noteworthy that core self-evaluations are related to both aspects of career success. Thus, our results are of value in theory-building regarding both core selfevaluations and career success and extend previous findings about dispositional antecedents of career success (Judge et al., 1999).

We can only speculate about the reasons why these relations did not hold true for the objective career success criteria when we measured CSE at T2 and the career success criteria at T1. It could be possible that there have been changes between both time points. First of all, there might have been changes in CSE. Test-retest reliability was .82, so the participants did not give exactly the same self-assessments. Second, there might have been changes in income or number of promotions so that the self-evaluation of participants with lower income or number of promotions was heightened or the self-evaluation of other participants who expected pay raises or a promotion in the near future was lessened. Finally, it might be an effect of common method variance. However, as income and number of promotions are objective indicators and CSE is a subjective self-assessment, we do not believe this to be the reason. Additionally, the change for job satisfaction is not significant. It is interesting to note that the reduction for career satisfaction is larger than the reduction for job satisfaction because career satisfaction (like both objective career success indicators) more directly relates to the career. This might substantiate the view that changes in career expectations albeit not in the job have somehow affected the self-assessment of CSE.

If we accept the notion that CSE is related in some way to various career success criteria, we have to answer the question why core self-evaluations are 
related to objective and subjective career success. With regard to objective career success, this could be due to job performance. Several studies have confirmed the relationship between core self-evaluations and job performance (Erez \& Judge, 2001; Judge et al., 2003). As Judge et al. (1999) assumed that "performance is one of the many determinants of extrinsic career outcomes" (p. 627), the relationship between core self-evaluations and objective career success could be mediated by performance.

With respect to subjective career success, there are two possible ways in which core self-evaluations and career success could be related. Judge and colleagues (1997; see also Dormann \& Zapf, 2001) suggested two mediation models for the relationship between core self-evaluations and job satisfaction. The first model assumes that people with core self-evaluations perceive their jobs as more challenging and thus are more satisfied with their jobs (perception-related mediation). A second possible model assumes that people with high core self-evaluations actually hold more complex and challenging jobs as a result of actions performed because of high core self-evaluations (action-related mediation). Both models could also be applied to the second indicator of subjective career success that was explored: career satisfaction.

On the one hand, people with high core self-evaluations may focus on career goals they have already achieved instead of the goals they have not realised so far (perception-related mediation). Furthermore, they feel responsible for their achievements and are, therefore, more satisfied with their career so far. On the other hand, people with high core self-evaluations may undertake more actions to attain their career goals; therefore, they achieve these goals more often and as a consequence are more satisfied with their career (action-related mediation). A third possible mediation model could also apply: Supervisors judge employees with high core self-evaluations more favorably than others and thus support them more. Therefore, the employees experience more objective career success and accordingly are more satisfied with their career (other perception-related mediation).

\section{Limitations and Implications}

Despite the accumulated evidence for the validity of the German version of the Core Self-Evaluations Scale, a limitation of our study regarding objective career success has to be mentioned. Although number of promotions and salary are observable and measurable and are therefore defined as indicators of objective career success, we assessed these variables via self-report. It is possible that people with positive core self-evaluations perceive a job change as promotion whereas people with low core self-evaluations do not. The same argument is possible, though more difficult to make, for salary: it is possible (though perhaps not likely) that people with high core self-evaluations may take all aspects regarding reward (financial and non-financial incentives) into

(C) 2010 The Authors. Applied Psychology: An International Review (C) 2010 International Association of Applied Psychology. 
account and thus report a higher income. Therefore, even though they are defined as objective these indicators could be biased by core self-evaluations. On the other hand, Judge and colleagues (1995) reported that archival salary was closely related to self-report salary. As a second limitation, not only salary and number of promotions but all variables were assessed via selfreport, i.e. the validity of our results could be threatened by common method variance (CMV). However, as Spector (2006) pointed out, CMV as a substantial threat to validity of studies solely using self-report measures is an urban legend. First, it could be a threat only in cases where the constructs are not measured in the best way by self-report. This is not the case, for example, for assessments of satisfaction (e.g. job, career, or life satisfaction) or assessments of self-concepts like core self-evaluations. Second, as far as CMV might elevate correlations between constructs measured with the same method statistically controlling for other constructs (e.g. negativity) should reduce this methodological bias. Finally, following the suggestions of Podsakoff, MacKenzie, Lee, and Podsakoff (2003) for attenuating limitations resulting from CMV we measured the criteria in sample 3 at different points in time. It has to be noted, though, that the age of the participants in this particular sample differs from the age of the participants in the other samples because job newcomers were analysed. This poses a threat to the generalisability of the findings in this sample.

\section{Conclusion}

The Core Self-Evaluations Scale by Judge and colleagues (2003) is a validated and reliable instrument to assess core self-evaluations economically. Our study provided evidence for the validity of a German version of the scale and provided further support for the cross-cultural generalisation of the core self-evaluations personality construct. Additionally, we confirmed relations with the most important indicators of career success. The Core SelfEvaluation Scale is applicable both in research and practice. With regard to research, the scale can be used to further examine the core self-evaluations construct and its relations to other constructs and vocational criteria, e.g. in research on social relationships like leader-member interactions. With regard to practice, the scale can be used to control for personality effects in personnel selection processes, in needs assessments in human resource development, or in employee surveys.

\section{REFERENCES}

Allen, N.J., \& Meyer, J.P. (1990). The measurement and antecedents of affective, continuance and normative commitment to the organization. Journal of Occupational Psychology, 63, 1-18.

(C) 2010 The Authors. Applied Psychology: An International Review (C) 2010 International Association of Applied Psychology. 
Arbuckle, J.L. (2006). AMOS 6.0. Spring House, PA: AMOS Development Corporation.

Barrick, M.R., \& Mount, M.K. (2005). Yes, personality matters: Moving on to more important matters. Human Performance, 18, 359-372.

Barrick, M.R., Mount, M.K., \& Judge, T.A. (2001). Personality and performance at the beginning of the new millennium: What do we know and where do we go next? International Journal of Selection and Assessment, 9, 9-20.

Beal, D.J., Trougakos, J.P., Weiss, H.M., \& Green, S.G. (2006). Episodic processes in emotional labor: Perceptions of affective delivery and regulation strategies. Journal of Applied Psychology, 91, 1053-1065.

Best, R.G., Stapleton, L.M., \& Downey, R.G. (2005). Core self-evaluations and job burnout: The test of alternative models. Journal of Occupational Health Psychology, 10, 441-451.

Bollen, K.A. (1989). Structural equations with latent variables. New York: Wiley.

Bollen, K.A., \& Stine, R.A. (1992). Bootstrapping goodness-of-fit measures in structural equation models. Sociological Methods and Research, 21, 205229.

Bono, J.E., \& Colbert, A.E. (2005). Understanding responses to multi-source feedback: The role of core self-evaluations. Personnel Psychology, 58, 171203.

Bono, J.E., \& Judge, T.A. (2003). Core self-evaluations: A review of the trait and its role in job satisfaction and job performance. European Journal of Personality, 17, S5-S18.

Borkenau, P., \& Ostendorf, F. (1993). NEO-Fünf-Faktoren-Inventar (NEO-FFI) [NEO-Five-Factor-Inventory (NEO-FFI)]. Göttingen: Hogrefe.

Boudreau, J.W., Boswell, W.R., \& Judge, T.A. (2001). Effects of personality on executive career success in the United States and Europe. Journal of Vocational Behavior, 58, 53-81.

Costa, P.T.J., \& McCrae, R. (1992). NEO-PI-R and NEO-FFI professional manual. Odessa, FL: Psychological Assessment Resources.

Diener, E., Emmons, R.A., Larsen, R.J., \& Griffin, S. (1985). The satisfaction with life scale. Journal of Personality Assessment, 49, 71-75.

Dilchert, S., \& Ones, D.S. (2008). Personality and extrinsic career success: Predicting managerial salary at different organizational levels. Zeitschrift für Personalpsychologie, 7, 1-23.

Dormann, C., \& Zapf, D. (2001). Job satisfaction: a meta-analysis of stabilities. Journal of Organizational Behavior, 22, 483-504.

Erez, A., \& Judge, T.A. (2001). Relationship of core self-evaluations to goal setting, motivation, and performance. Journal of Applied Psychology, 86, 1270-1279.

Greenhaus, J.H., Parasuraman, S., \& Wormley, W.M. (1990). Effects of race on organizational experiences, job-performance evaluations, and career outcomes. Academy of Management Journal, 33, 64-86.

Hülsheger, U.R., \& Maier, G.W. (2008). Persönlichkeitseigenschaften, Intelligenz und Erfolg im Beruf: Eine Bestandsaufnahme internationaler und nationaler Forschung. [Personality traits, intelligence and success at work: A review of international and national findings]. Psychologische Rundschau, 58, 108-122. 
Hülsheger, U.R., Specht, E., \& Spinath, F.M. (2006). Validität des BIP und des NEO-PI-R: Wie geeignet sind ein berufsbezogener und ein nicht explizit berufsbezogener Persönlichkeitstest zur Erklärung von Berufserfolg? [Validity of the BIP and the NEO-PI-R: How suitable are an explicitly job-oriented and a general personality test for the explanation of career success?] Zeitschrift für Arbeits- und Organisationspsychologie, 50, 135-147.

Judge, T.A. (2009). Core self-evaluations and work success. Current Directions in Psychological Science, 18, 58-62.

Judge, T.A., \& Bono, J.E. (2001). Relationship of core self-evaluations traitsself-esteem, generalized self-efficacy, locus of control, and emotional stabilitywith job satisfaction and job performance: A meta-analysis. Journal of Applied Psychology, 86, 80-92.

Judge, T.A., Bono, J.E., Erez, A., \& Locke, E.A. (2005). Core self-evaluations and job and life satisfaction: The role of self-concordance and goal attainment. Journal of Applied Psychology, 90, 257-268.

Judge, T.A., Bono, J.E., \& Locke, E.A. (2000). Personality and job satisfaction: The mediating role of job characteristics. Journal of Applied Psychology, 85, 237-249.

Judge, T.A., Cable, D.M., Boudreau, J.W., \& Bretz, R.D. (1995). An empirical investigation of the predictors of executive career success. Personnel Psychology, $48,485-519$.

Judge, T.A., Erez, A., \& Bono, J.E. (1998). The power of being positive: The relation between positive self-concept and job performance. Human Performance, 11, 167187.

Judge, T.A., Erez, A., Bono, J.E., \& Thoresen, C.J. (2002). Are measures of selfesteem, neuroticism, locus of control, and generalized self-efficacy indicators of a common core construct? Journal of Personality and Social Psychology, 83, 693710 .

Judge, T.A., Erez, A., Bono, J.E., \& Thoresen, C.J. (2003). The Core Self-Evaluations Scale: Development of a measure. Personnel Psychology, 56, 303-331.

Judge, T.A., Heller, D., \& Klinger, R. (2008). The dispositional sources of job satisfaction: A comparative test. Applied Psychology: An International Review, 57, 361-372.

Judge, T.A., Higgins, C.A., Thoresen, C.J., \& Barrick, M.R. (1999). The Big Five personality traits, general mental ability, and career success across the life span. Personnel Psychology, 52, 621-652.

Judge, T.A., \& Hurst, C. (2007). Capitalizing on one's advantages: Role of core self-evaluations. Journal of Applied Psychology, 92, 1212-1227.

Judge, T.A., \& Larsen, R.J. (2001). Dispositional affect and job satisfaction: A review and theoretical extension. Organizational Behavior and Human Decision Processes, 86, 67-98.

Judge, T.A., Locke, E.A., \& Durham, C.C. (1997). The dispositional causes of job satisfaction: A core evaluation approach. Research in Organizational Behavior, 19, 151-188.

Judge, T.A., Locke, E.A., Durham, C.C., \& Kluger, A.N. (1998). Dispositional effects on job and life satisfaction: The role of core evaluations. Journal of Applied Psychology, 83, 17-34. 
Judge, T.A., Van Vianen, A.E.M., \& De Pater, I.E. (2004). Emotional stability, core self-evaluations, and job outcomes: A review of the evidence and an agenda for future research. Human Performance, 17, 325-346.

Kilduff, M., \& Day, D.V. (1994). Do chameleons get ahead? The effects of selfmonitoring on managerial careers. Academy of Management Journal, 37, 10471060.

Krampen, G. (1991). Fragebogen zu Kompetenz- und Kontrollüberzeugungen [Questionnaire on capacity and locus of control beliefs]. Göttingen: Hogrefe.

Krohne, H.W., Egloff, B., Kohlmann, C.-W., \& Tausch, A. (1996). Untersuchungen mit einer deutschen Version der "Positive and Negative Affect Schedule" (PANAS) [Investigations with a German version of the Positive and Negative Affect Schedule (PANAS)] Diagnostica, 42, 139-156.

Laschinger, H.K.S., Purdy, N., \& Almost, J. (2007). The impact of leader-member exchange quality, employment and core self-evaluation on nurse manager's job satisfaction. Journal of Nursing Administration, 37, 221-229.

Levenson, H. (1981). Differentiating among internality, powerful others, and chance. In H.M. Lefcourt (Ed.), Research with the locus of control construct (pp. 15-63). New York: Academic Press.

Maier, G.W. (2001). Deutsche Übersetzung der satisfaction with life scale (Forschungsbericht) [German translation of the satisfaction with life scale]. Research Report, Universität München.

Maier, G.W., \& Woschée, R.-M. (2002). Die affektive Bindung an das Unternehmen-Psychometrische Überprüfung einer deutschsprachigen Fassung des Organizational Commitment Questionaire (OCQ) von Porter und Smith (1970) [Affective commitment to an organisation: Psychometric examination of a German version of the Organisational Commitment Questionnaire (OCQ) of Porter and Smith (1970)]. Zeitschrift für Arbeits- und Organisationspsychologie, 46, 126-136.

Mardia, K.V. (1985). Mardia's test of multinormality. In S. Kotz \& N.L. Johnson (Eds.), Encyclopedia of statistical sciences (Vol. 5, pp. 217-221). New York: Wiley.

Mathieu, J.E., \& Zajac, D.M. (1990). A review and meta-analysis of the antecedents, correlates, and consequences of organizational commitment. Psychological Bulletin, 108, 171-194.

Meng, X.L., Rosenthal, R., \& Rubin, D.B. (1992). Comparing correlated correlation coefficients. Psychological Bulletin, 111, 172-175.

Neuberger, O., \& Allerbeck, M. (1978). Messung und Analyse von Arbeitszufriedenheit [Measurement and analysis of job satisfaction]. Bern: Huber.

Ng, T.W.H., Eby, L.T., Sorensen, K.L., \& Feldman, D.C. (2005). Predictors of objective and subjective career success: A meta-analysis. Personnel Psychology, 58, $367-408$.

Ng, T.W.H., Sorensen, K.L., \& Eby, L.T. (2006). Locus of control at work: A meta-analysis. Journal of Organizational Behavior, 27, 1057-1087.

Nikolaou, I., \& Judge, T.A. (2007). Fairness reactions to personnel selection techniques in Greece: The role of core self-evaluations. International Journal of Selection and Assessment, 15, 206-219. 
Piccolo, R.F., Judge, T.A., Takahashi, K., Watanabe, N., \& Locke, E.A. (2005). Core self-evaluations in Japan: Relative effects on job satisfaction, life satisfaction, and happiness. Journal of Organizational Behavior, 26, 965-984.

Podsakoff, P.M., MacKenzie, S.B., Lee, J.Y., \& Podsakoff, N.P. (2003). Common method biases in behavioral research: A critical review of the literature and recommended remedies. Journal of Applied Psychology, 88, 879-903.

Porter, L.W., \& Smith, F.J. (1970). The etiology of organizational commitment. University of California at Irvine.

Rosenberg, M. (1965). Society and the adolescent self-image. Princeton, NJ: Princeton University Press.

Salvaggio, A.N., Schneider, B., Nishii, L.H., Mayer, D.M., Ramesh, A., \& Lyon, J.S. (2007). Manager personality, manager service quality orientation, and service climate: Test of a model. Journal of Applied Psychology, 92, 1741-1750.

Schmidt, K.-H., Hollmann, S., \& Sodenkamp, D. (1998). Psychometrische Eigenschaften und Validität einer deutschen Fassung des "Commitment"-Fragebogens von Allen und Meyer (1990) [Psychometric properties and validity of a German version of Allen and Meyer's (1990) questionnaire for measuring organisational commitment]. Zeitschrift für Differentielle und Diagnostische Psychologie, 19, 93-106.

Schmitt, N. (2004). Beyond the Big Five: Increases in understanding and practical utility. Human Performance, 17, 347-357.

Schwarzer, R., \& Jerusalem, M. (1999). Skalen zur Erfassung von Lehrer- und Schülermerkmalen. Dokumentation der psychometrischen Verfahren im Rahmen der Wissenschaftlichen Begleitung des Modellversuchs Selbstwirksame Schulen [Scales for the assessment of teacher and pupil attributes]. Berlin: Freie Universität Berlin.

Seibert, S.E., Crant, J.M., \& Kraimer, M.L. (1999). Proactive personality and career success. Journal of Applied Psychology, 84, 416- 427.

Seibert, S.E., \& Kraimer, M.L. (2001). The five-factor model of personality and career success. Journal of Vocational Behavior, 58, 1-21.

Spector, P.E. (1988). Development of the Work Locus of Control Scale. Journal of Occupational Psychology, 61, 335-340.

Spector, P.E. (2006). Method variance in organizational research: Truth or urban legend? Organizational Research Methods, 9, 221-232.

Thoresen, C.J., Kaplan, S.A., Barsky, A.P., Warren, C.R., \& de Chermont, K. (2003). The affective underpinnings of job perceptions and attitudes: A meta-analytic review and integration. Psychological Bulletin, 129, 914-945.

Tokar, D.M., Fischer, A.R., \& Subich, L.M. (1998). Personality and vocational behavior: A selective review of the literature, 1993-1997. Journal of Vocational Behavior, 53, 115-153.

Van de Vijver, F., \& Hambleton, R.K. (1996). Translating tests: Some practical guidelines. European Psychologist, 1, 89-99.

von Collani, G., \& Herzberg, P.Y. (2003). Zur internen Struktur des globalen Selbstwertgefühls nach Rosenberg [On the internal structure of global self-esteem (Rosenberg)]. Zeitschrift für Differentielle und Diagnostische Psychologie, 24, 922 .

(C) 2010 The Authors. Applied Psychology: An International Review (C) 2010 International Association of Applied Psychology. 
Wanberg, C.R., Glomb, T.M., Song, Z., \& Sorensen, S. (2005). Job-search persistence during unemployment: A ten wave longitudinal study. Journal of Applied Psychology, 90, 411-430.

Watson, D., Clark, L.A., \& Tellegen, A. (1988). Development and validation of brief measures of positive and negative affect-The PANAS scales. Journal of Personality and Social Psychology, 54, 1063-1070.

West, S.G., Finch, J.F., \& Curran, P.J. (1995). Structural equation models with nonnormal variables: Problems and remedies. In R.H. Hoyle (Ed.), Structural equation modelling: Concepts, issues, and applications (pp. 56-75). Thousand Oaks, CA: Sage.

\section{APPENDIX}

Original and Translated Items of the Core Self-Evaluations Scale

\begin{tabular}{|c|c|c|}
\hline \multicolumn{2}{|l|}{ Original item } & German item \\
\hline $\begin{array}{l}\text { I am confident I get the success } \\
\text { I deserve in life. }\end{array}$ & & $\begin{array}{l}\text { Ich bin zuversichtlich, im Leben den Erfolg zu } \\
\text { bekommen, den ich verdiene. }\end{array}$ \\
\hline Sometimes I feel depressed. & (r) & Manchmal bin ich deprimiert. \\
\hline $\begin{array}{l}\text { When I try, I generally } \\
\text { succeed. }\end{array}$ & & $\begin{array}{l}\text { Wenn ich mich anstrenge, bin ich im Allgemeinen } \\
\text { erfolgreich. }\end{array}$ \\
\hline $\begin{array}{l}\text { Sometimes when I fail I feel } \\
\text { worthless. }\end{array}$ & (r) & $\begin{array}{l}\text { Wenn ich etwas nicht schaffe, fühle ich mich } \\
\text { manchmal wertlos. }\end{array}$ \\
\hline I complete tasks successfully. & & Ich erledige Aufgaben erfolgreich. \\
\hline $\begin{array}{l}\text { Sometimes, I do not feel in } \\
\text { control of my work. }\end{array}$ & (r) & $\begin{array}{l}\text { Manchmal habe ich das Gefühl, keine Kontrolle } \\
\text { über meine Arbeit zu haben. }\end{array}$ \\
\hline $\begin{array}{l}\text { Overall, I am satisfied with } \\
\text { myself. }\end{array}$ & & Im Großen und Ganzen bin ich mit mir zufrieden. \\
\hline $\begin{array}{l}\text { I am filled with doubts about } \\
\text { my competence. }\end{array}$ & (r) & Ich zweifle an meinen Fähigkeiten. \\
\hline $\begin{array}{l}\text { I determine what will happen } \\
\text { in my life. }\end{array}$ & & Ich bestimme, was in meinem Leben geschehen soll. \\
\hline $\begin{array}{l}\text { I do not feel in control of my } \\
\text { success in my career. }\end{array}$ & (r) & $\begin{array}{l}\text { Ich habe das Gefühl, den Erfolg meiner Karriere } \\
\text { nicht unter Kontrolle zu haben. }\end{array}$ \\
\hline $\begin{array}{l}\text { I am capable of coping with } \\
\text { most problems. }\end{array}$ & & $\begin{array}{l}\text { Ich bin in der Lage, die meisten meiner Probleme zu } \\
\text { bewältigen. }\end{array}$ \\
\hline $\begin{array}{l}\text { There are times when things } \\
\text { look pretty bleak and } \\
\text { hopeless to me. }\end{array}$ & (r) & $\begin{array}{l}\text { Es gibt Zeiten, in denen mir die Dinge ziemlich } \\
\text { düster und hoffnungslos erscheinen. }\end{array}$ \\
\hline
\end{tabular}

Note: $(\mathrm{r})=$ reverse coded. Original items from Judge et al. (2003). Printed with permission of Wiley-Blackwell Publishing Ltd. 